\title{
Analysis of Pathological Manifestations in Buildings at The University City Prof. José da Silveira Netto, Located in Belém-PA
}

\author{
Catarina de Nazaré Pereira Pinheiro, Adriene Rodrigues Barbosa
}

\begin{abstract}
The reinforced concrete structures are present in most constructions around the world and can be defined as a composite material of concrete reinforced with steel bars. Those structures may exhibit pathologies during the construction stage or after, due to several types of failures, whether is in the project, execution or maintenance. The Universidade Federal do Pará, has great influence over Brazil, being considered the biggest university in the north of the country. Despite its relevance, the university campus presents numerous problems in their building structures. The purpose of this paper is to identify the pathologies in the older and most recent reinforced concrete buildings existing at the Cidade Universitária Prof. José da Silveira Netto, Guamá campus, located in Belém, state's capital, enabling the evaluation of corrective maintenance needs of the most deteriorated constructions. To support the case study, it was performed a visual analysis with photographic register, allied to theoretical study regarding the subject, enabling the identification of possible causes of the alterations. The results show pathologies from many fields, from structure design until foundation of the buildings. The reduction in the occurrence of those manifestations would be possible, with better supervision during the construction process and preventive maintenance, whose lack of were the main cause of the identified pathologies.
\end{abstract}

Index Terms: Building Pathologies Evaluation; Case Study; Pathological Manifestations

\section{INTRODUCTION}

Concrete is a heterogeneous compound resulting from the mixing of water, cement, large and small aggregates and, in some cases, additives. According to [10], one of the characteristics of this material is the high compressive strength, but low to traction. To increase this resistance, it is necessary to insert a material that resists traction, such as steel. In this sense, [4] defines the concept of reinforced concrete as the union of concrete with steel, in such a way that both support jointly the applicant efforts.

The use of reinforced concrete structures is widespread throughout the world. [9] relate this use with the ease of execution of these structures, low cost, and their variety of shapes and sizes. In addition, [5] describes the material as having high durability when regularly maintained. However, due to the lack of constant maintenance, several pathological manifestations may arise in these structures.

Revised Manuscript Received on June 7, 2019.

Catarina de Nazaré Pereira Pinheiro, Adriene Rodrigues Barbosa, Federal University of Pará
These manifestations result in a decrease in the durability of these structures and, consequently, their useful life. The latter is defined, according to [1], as the period in which the building, its elements and components, carry out the activities for which they were designed and constructed, respecting the levels of performance provided in the standard and the maintenance processes specified in your operating, operation and maintenance manual.

The lifecycle of a structure must be defined during the design phase, and its conservation depends directly on the execution of preventive and corrective maintenance. The first case is related to the periodic maintenance that is done in order to prevent the occurrence of pathological manifestations. On the other hand, the correction is performed with the intention of healing some pathology present in the structure and corresponds to the identification and correction of the pathological manifestations found.

Thus, the goal of this paper is to identify the pathological manifestations and their possible causes, in reinforced concrete structures present in the José da Silveira Netto University City, located in the city of Belém-PA, in order to assist the execution of corrective maintenance in the buildings . In addition, the possible solutions to the problems were identified.

\section{METHODOLOGY}

The methodology of this work was based on the theoretical conceptualization, the case study and the report elaboration with the manifestations found. The first part refers to the bibliographic research about the most relevant subjects to the study, based on the consultation of books, guidelines and academic productions like monographs, dissertations and theses.

The case study is related to the identification of the manifestations present in ten buildings located the University City. For this, a site visit was carried out and, through visual inspection and with the aid of photographic records, the pathologies existing in the reinforced concrete structures of the main buildings on the university were identified. It should be noted that due to the extension of the complex, not all buildings were inspected, only the most relevant to the University Campus.

After the identification of the manifestations and with the assistance of a 
bibliographical revision, the report with the main pathologies identified was elaborated and also included possible causes and solutions.

\section{CASE STUDY}

\section{A. Site Characterization}

In this study, concrete structures were analyzed in some buildings of Cidade Universitária José da Silveira Neto, located in Belém-PA (Figure 01). The city is home to the Belém campus of the Federal University of Pará (Figure 02), with a territorial area corresponding to approximately $3,328,655.80 \mathrm{~m}^{2}$ and a built area of approximately $204,930.90 \mathrm{~m}^{2}$

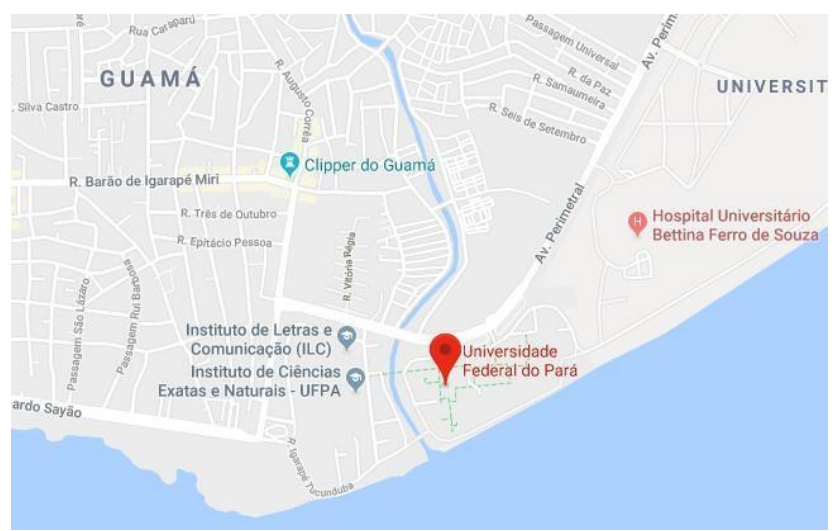

Fig. 1: Location of Federal University of Pará (Source: Google Maps, 2019)

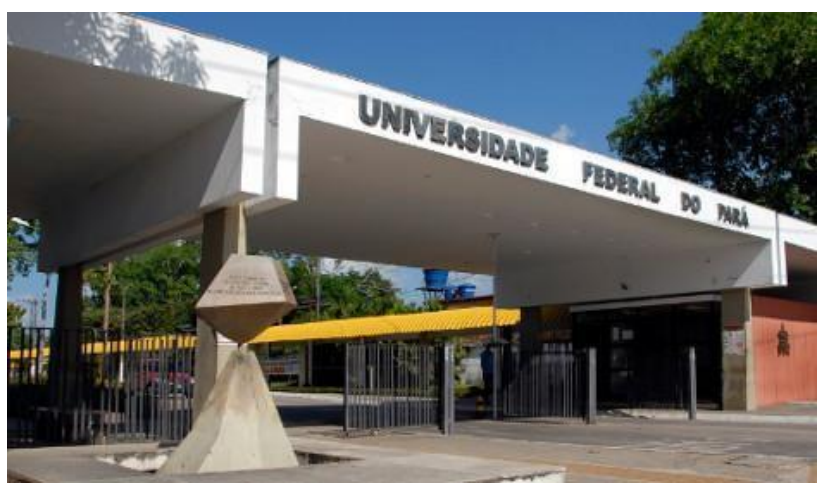

Fig. 2: Federal University of Pará (Source: UFPA Website, 2019)

Among the buildings analyzed in the University City, are its Rectory, the Benedito Nunes Events Center, some classroom pavilions and the university's Civil Engineering Laboratory. Most of the analyzed elements were exposed to the external environment, with high moisture content, favorable to the appearance of several pathological manifestations.

\section{B. Survey of Pathological Manifestations}

According to [7], concrete is a receptive material to the microbiological attack, when combined with favorable environmental conditions, due to its conditions of roughness, humidity, chemical composition and porosity. These micro-organisms can interfere from the esthetics of the concrete to its integrity, reducing its durability.

In the building of the rectory of the Federal University of Pará, the high moisture content, combined with the presence of some cracks and the material itself, contributed to the appearance of biological agents such as fungi in the concrete structures present in the building, in some cases, compromising the integrity of parts of those structures. (Figure 03).

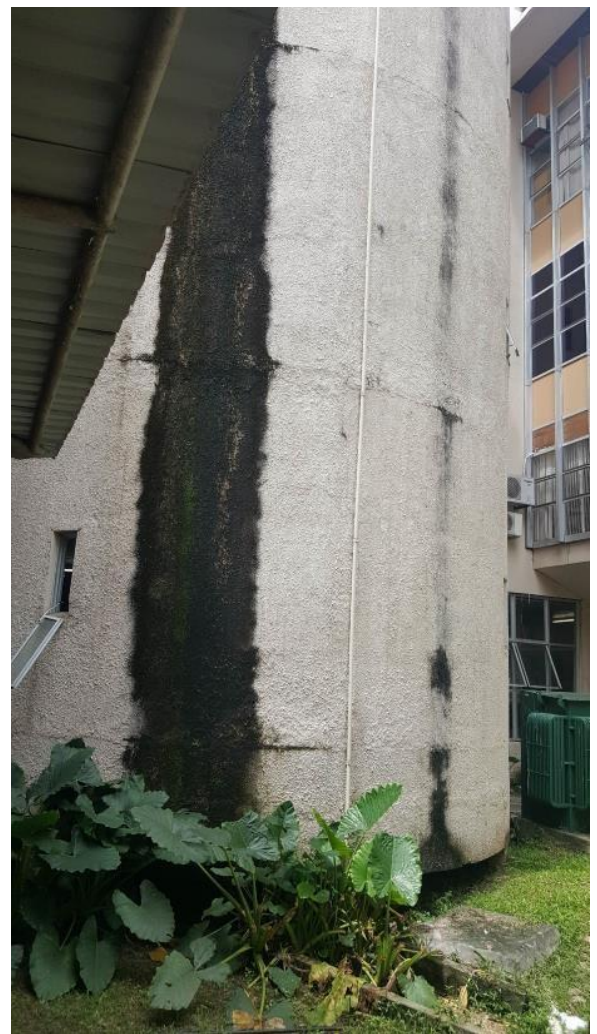

Fig. 3: Microbiological attack (Source: Author's Collection, 2019)

In addition to the microorganisms, in this building, there was a great presence of vegetation in the building (Figure 04). According to [11], there are two types of pathologies linked to plant life. The first is related to the emergence and proliferation of small algae in very porous concretes or cracks, and its main cause is the moisture present in the site. The second type refers to the appearance of cracked plants, which to a large extent can cause structural damage or even collapse of the building.

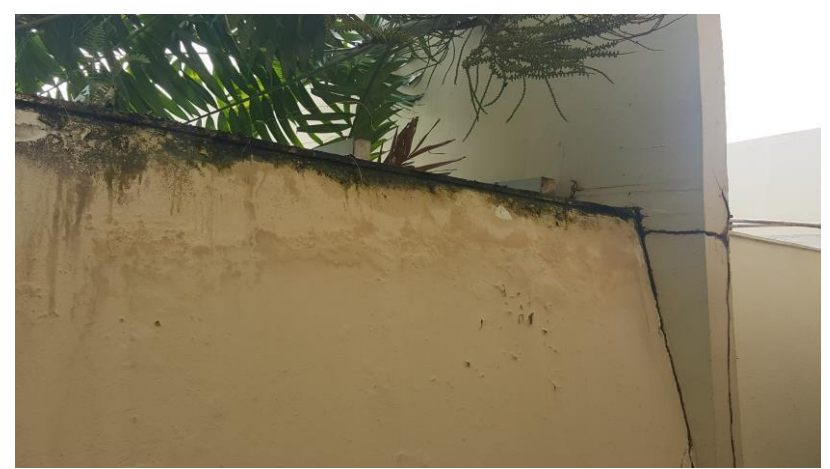

Fig. 4: Presence of vegetation (Source: Author's Collection, 2019)

In the rectory, some cracks and disintegration of the concrete were also found in parts of the structure, possibly caused by the material being in contact with the aggressive environment and by the presence of the biological agents, in the case of segregation (Figure 05). In a

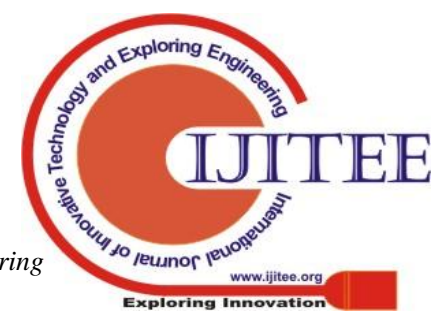


previous visual analysis, no indication of structural problems was found in this building.

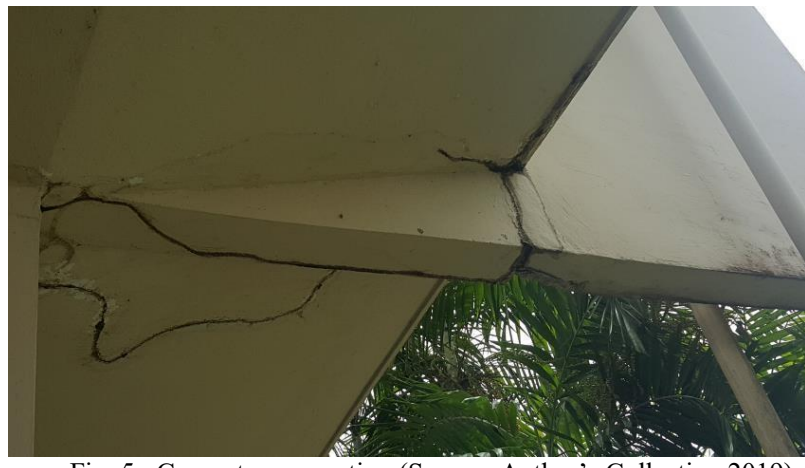

Fig. 5: Concrete segregation (Source: Author's Collection,2019)

The Center of Events Benedito Nunes has fundamental importance for the university because it receives the main academic events of the institution. In the concrete structures present in this building, problems were found, mainly of a structural nature, with the incidence of inclined, horizontal and vertical cracks in the pillars, beams and walls, which in a preliminary analysis are caused by mechanical loads of the structure (Figure 06).

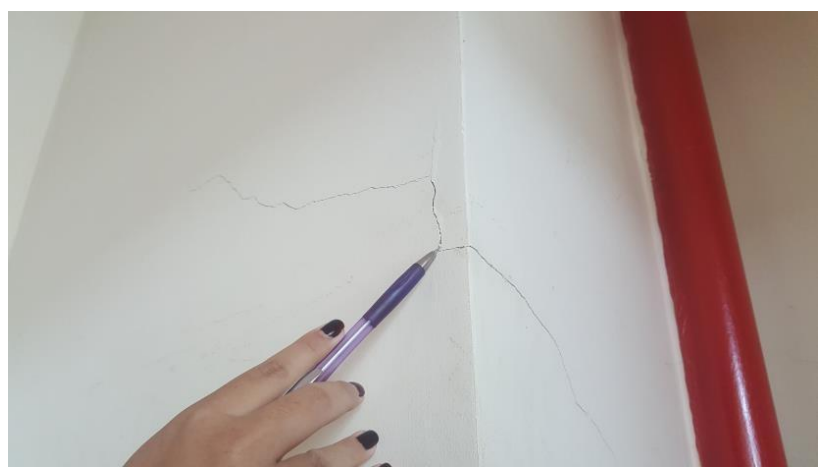

Fig. 6: Structural Problems (Source: Author’s Collection, 2019)

Fig. 7: Corrosion Process (Source: Author's Collection, 2019)



Fig. 7: Corrosion Process (Source: Author’s Collection, 2019)
During a previous visit to the building in 2016, several fissures could be observed, which were later corrected. However, in the year of this study, in 2019, it was noticed the reappearance of some cracks, mainly in the pillars of thestructure, which indicates these cracks encountered are in a active condition, pointing to a lack of solution to its causative problem. In addition to the pathologies highlighted above, the event center still presents several pathological manifestations of a constructive nature, which were addressed by [8].

According to [6], corrosion is generally defined as the destructive interaction of the environment with a material, caused by chemical, electrochemical or physical action. In reinforced concrete reinforcement, this process is electrochemical. Despite the alkalinity of the concrete, which involves steel, some phenomena such as the penetration of chlorides allow the increase of acidity in that material, causing corrosion of the reinforcement steel in these structures.

Most of the pillars of the footbridges that existed within the University City presented the corrosion process, which in some cases was quite high (Figures 07 and 08). The exposure of these structures to the external environment, with higher aggressiveness, was what possibly propitiated the phenomenon.

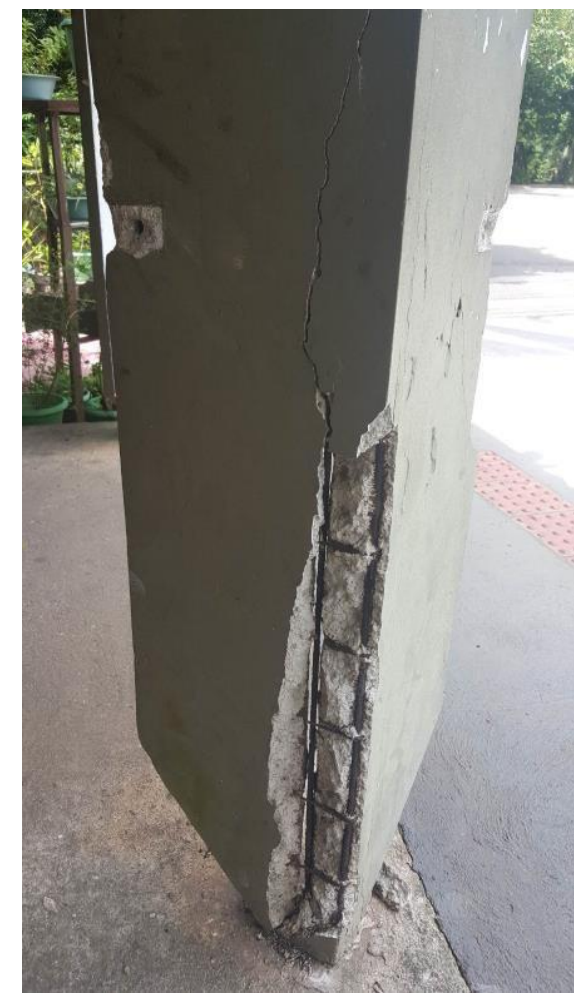

Fig. 8: Corrosion Process (Source: Author's Collection, 2019)

In the classroom pavilions, the concrete structures, in general, presented problems with biological agents 
(Figure 09), which, as in the rectory building, had as main cause the presence of moisture in the place.

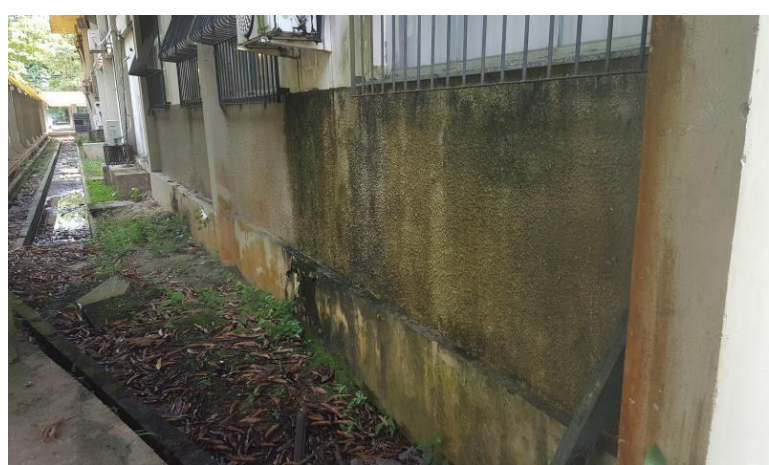

Fig. 9: Biological agents (Source: Author's Collection, 2019)

In addition, in the pavilions, there were several fissures and cracks in the beams, pillars and walls, caused by structural and structural problems. It is worth mentioning, in these buildings, the cracks caused by foundation problems. (Figures 10 and 11)



Fig. 10: Foundation Problems (Source: Author's Collection, 2019)

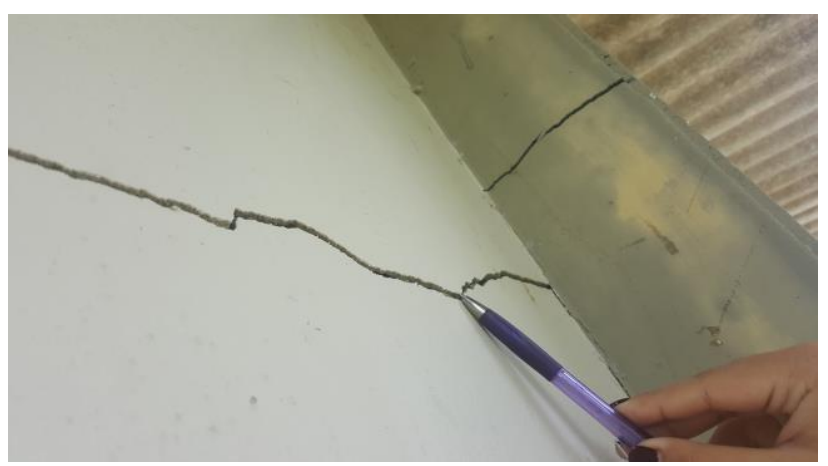

Fig. 11: Foundation Problems (Source: Author's Collection, 2019)

According to [3], the foundations are structural elements that transmit the load received from the structures to the soil, which must have the capacity to support these tensions. In this sense, soil study is of fundamental relevance. Clays, for example, tend to have a lower resistance than hard soils, such as sands. Thus, to determine the type and dimension of the foundations, a previous study of the type of soil found in the region is necessary.

Failures in the design or execution of these foundations, or in the construction of foundations of adjacent buildings, allow the movement of the soil and these structures, a phenomenon known as repression. According to [2] the fissures in the elements are visible manifestations of the problems caused by the movement of foundations.

Previous studies of the soil inside the University City have verified the predominant presence of clay in great depths. Due to the low resistance of this type of soil, it is common the greater incidence of problems of foundation, which was proven by the diverse manifestations found throughout the university.

In the building of the university's Civil Engineering laboratory, several manifestations, similar to those mentioned above, were found. The presence of several fissures and cracks, caused by the structural and construction problems previously mentioned, and the presence of vegetation and biological agents in the structures (Figures 12 and 13)



Fig. 12: Biological agents (Source: Author's Collection, 2019)

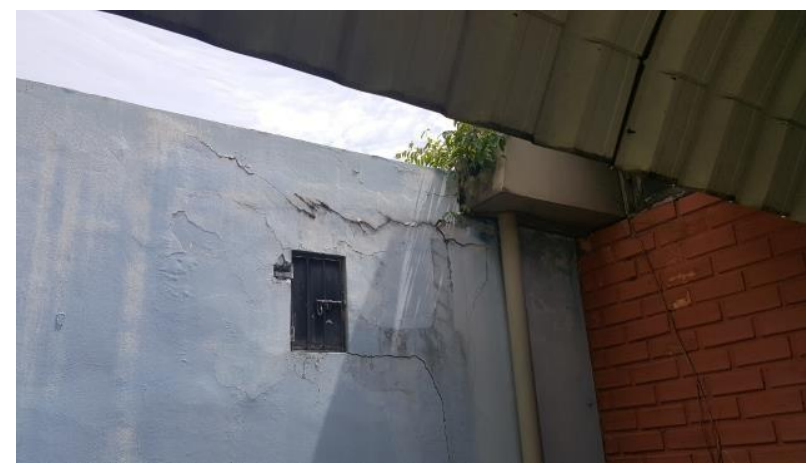

Fig. 13: Presence of vegetation(Source: Author's Collection, 2019)

\section{INTERVENTION PROPOSAL}

For the manifestations identified, the solutions proposed below were based on the scientific literature reviews. Problems related to biological agents can be solved by performing cleaning of contaminated surfaces and, where necessary, using fungicidal solutions and reconstitution of the concrete at more extreme levels of deterioration. For the vegetation, the main indicated solutions are the manual withdrawal or the use of herbicides, followed by the filling of the open joints or fissures.

[5] proposes as a solution to steel corrosion problems in reinforced concrete structures, the careful removal of the region affected by the phenomenon and the products that generated the corrosion by cleaning the surface and reconstituting the original section of the reinforcement. For cases with corrosion without compromise of concrete and steel bars, the author recommends the recovery of the structural element with the use of mortar based on 
cement, epoxy, or polyester, increasing the covering of the section when it is below that specified by the standard. In cases of structural element impairment, the author recommends reinforcement with increased section of the component. Finally, after reinforcement, the author recommends the application of protective coating on the structure.

For manifestations related to foundation, fissures and cracking problems, [5] recommends strengthening the foundation or the relief of load through a specialist in the area, the preparation and cleaning of cracks or cracks, and the injection of epoxy resin. For cracks and cracks arising from structural problems, appropriate structural reinforcement is recommended.

The following is a table describing the main manifestations and repairs succinctly, as indicated above.

Table 1 - List of Manifestations Found and Proposed Solutions

\begin{tabular}{|c|c|}
\hline Manifestation & Proposed Solution \\
\hline $\begin{array}{l}\text { Stains due to } \\
\text { moisture }\end{array}$ & Surface cleaning and brushing \\
\hline $\begin{array}{c}\text { Presence of } \\
\text { microorganisms }\end{array}$ & $\begin{array}{c}\text { Surface cleaning and application } \\
\text { of fungicide solution }\end{array}$ \\
\hline $\begin{array}{l}\text { Fissures and } \\
\text { Cracks }\end{array}$ & $\begin{array}{l}\text { Verification of fissure activity, } \\
\text { preparation and cleaning of fissures } \\
\text { or cracks, injection of epoxy resin, } \\
\text { and more profound analyses in case } \\
\text { of active fissures }\end{array}$ \\
\hline $\begin{array}{l}\text { Presence of } \\
\text { Vegetation }\end{array}$ & $\begin{array}{l}\text { Manual removal of vegetation, } \\
\text { application of herbicides,filling } \\
\text { of the openings in the concrete } \\
\text { and cleaning of the surface for } \\
\text { the presence of algae }\end{array}$ \\
\hline $\begin{array}{l}\text { Concrete } \\
\text { Corrosion }\end{array}$ & $\begin{array}{l}\text { Removal of the region affected by } \\
\text { corrosion, reconstitution of the } \\
\text { original section with mortar with } \\
\text { adequate base when there is no more } \\
\text { severe damage, enlargement of the } \\
\text { section in cases of structural } \\
\text { impairment, increase of the cover } \\
\text { when in disagreement with the } \\
\text { current norm and application of } \\
\text { protective coating in the structure }\end{array}$ \\
\hline $\begin{array}{c}\text { Structural } \\
\text { Manifestations }\end{array}$ & $\begin{array}{l}\text { Structural reinforcement of the } \\
\text { structure according to suitable } \\
\text { structural design }\end{array}$ \\
\hline $\begin{array}{l}\text { Foundation } \\
\text { Issues }\end{array}$ & $\begin{array}{l}\text { Relief of load when possible, or } \\
\text { reinforcement of foundation according } \\
\text { to appropriate specialist in the area }\end{array}$ \\
\hline
\end{tabular}

\section{CONCLUSIONS}

Despite the high durability of reinforced concrete, the lack of maintenance, along with the aggressive external environmental conditions, provoke several pathological manifestations in these structures. In the Cidade Universitária José da Silveira Netto, all the buildings studied had some kind of pathological manifestation.

The main manifestations identified in the building were the spots by action of microorganisms present in the structure, fissures and cracks, presence of vegetation, corrosion of reinforced concrete reinforcement, as well as problems related to foundation or structure. Most of the problems listed above were associated with the high moisture content present due to exposure to the external area or due to infiltration problems.

The use of reinforced concrete structures is common, and depends on several factors such as environmental and human. The environmental aggressiveness class is an intrinsic factor of the site, so the structure must be constructed according to the environment in which it is located. The human factor depends on the care with maintenance and use of the building. The execution of frequent preventive maintenance would avoid the appearance of diverse pathological manifestations in the studied buildings and, consequently, would reduce the expenses with reforms.

\section{REFERENCES}

1. ABNT, Associação Brasileira de Normas Técnicas. NBR 15575 Edificações habitacionais - Desempenho. Brasil, 2013.

2. ALVES, J. R. Levantamento das manifestações patológicas em fundações e estruturas nas edificações, com até dez anos de idade, executadas no estado de Goiás. 131f. Dissertação. Escola de Engenharia Civil - Universidade Federal de Goiás, 2009.

3. AZEREDO, H. A. O Edifício Até sua Cobertura. São Paulo. Ed. Edgar Blucher Ltda, 1977.

4. BASTOS, P. S. S. Fundamentos do concreto armado: Notas de aula Unesp, Bauru, 2006.

5. HELENE, P. R. L. Manual para Reparo, Reforço e Proteção de Estruturas de Concreto. 2. ed. São Paulo: Ed. Pini, 1992.

6. HELENE, P. R. L. Contribuição ao estudo da corrosão em armaduras de concreto armado. 231 f. Tese (Livre-Docência) - Escola Politécnica da Universidade de São Paulo, São Paulo, 1993.

7. LAPA, J.S. Patologia, Recuperação e Reparo das Estruturas de Concreto. 56f. Monografia - Curso Engenharia Civil, Universidade Federal de Minas Gerais, Minas Gerais, 2008.

8. MAFRA, J.; BALTAZAR, B.; ARAÚJO, A.; GUSMÃO, R.; SOUZA A. Análise das manifestações patológicas visando concepção de plano de manutenção corretiva para o Centro de Convenções Benedito Nunes, em Belém-Pa, Congresso Internacional sobre Patologia e Reabilitação de Estruturas. Crato (Ceará), 2017.

9. MEHTA, P. K.; MONTEIRO, P. J. M. Concreto: estrutura, propriedades e materiais. São Paulo: Ed. PINI, 1994.

10. SOUZA, V.C.M.; RIPPER, Thomaz. Patologia, recuperação e reforço de estruturas de concreto. 262 p. São Paulo. Ed. PINI, 1998.

11. RIPPER, T Patologia, recuperação e reforço de estruturas de concreto. 262f. 1. ed. São Paulo: Editora PINI Ltda, abril, 2009.CUNHA, Maria Clementina Pereira. (Org.) O Direito à Memória: patrimônio histórico e cidadania. São Paulo: Departamento do Patrimônio Histórico, 1992, p. 25 .

\section{AUTHORS PROFILE}

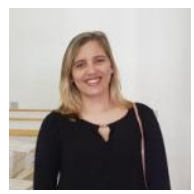

Catarina Pinheiro graduated in Civil Engineering from the Federal University of Pará and currently graduate student in structures and materials from the Federal University of Rio de Janeiro. Professionally, she has an experience with renovation and restoration, construction management, and teaching. In the academic field, she worked on research lines of renovation and restoration, optimization, concrete structures, structural modeling and currently viscoelasticity and meshless method.

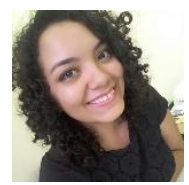

Adriene Barbosa I am an undergrad student of Civi Engineering at Federal University of Pará, with a minor in Sustainable Infrastructure from University of California, San Diego. 